\title{
The Syrian Commercial Elite and Mamluk State- Building in the Fifteenth Century
}

\author{
Patrick Wing
}

In Rajab 889/July-August 1484, the Mamluk sultan al-Ashraf Qāytbāy appointed Shams al-Dīn Muhammad b. al-Muzalliq chief Shāfīi qāọ̄ in Damascus. ${ }^{1}$ This office was the most distinguished and lucrative post for members of the religious elite in late medieval Syria, and the holder of this position enjoyed a status as a high-ranking member of the 'ulamā', as well as substantial material compensation and power within the ruling hierarchy of the state. Shams al-Dīn's family had been a cornerstone of the economy and social fabric of Damascus for most of the $15^{\text {th }}$ century, and provides an illustration of the historical changes that affected the development of the Sultanate more broadly in this period. The $q \bar{a} d \vec{\imath}$ s grandfather, also known as Shams al-Dīn, Muhammad b. 'Alì b. al-Muzalliq, was not a judge, but made the family's fortune in trade with India in the late 8 th $/ 14^{\text {th }}$ and early 9 th $/ 15^{\text {th }}$ centuries. His commercial contacts, in combination with the political alliances he forged during the period of civil war in Syria in the first decade of the 9 th $/ 15^{\text {th }}$ century, assured his family's position of wealth and influence for generations to come. In this chapter we consider what the history of the Banū Muzalliq at Damascus suggests about the historical development of the Mamluk Sultanate's state. Members of the family were merchants involved in Indian Ocean and Red Sea trade in the Hijaz, as well as Syria, filled positions in the military and financial administration of the Sultanate by the second generation, and occupied roles in the religious judiciary by the third. The Muzalliq family aligned their interests locally in Damascus, as well as transregionally, with those of the sultans, beginning in a period at the start of the 9 th $/ 15^{\text {th }}$ century when Syria had fallen outside of the direct control of Cairo, and gradually integrated with the Sultanate's political elite as Syria itself was more firmly re-integrated into the realm. An examination of the commercial elite of Syria suggests parallels to the broadening of the Sultanate's religious and intellectual elite of the same period, as individuals with ties outside the Cairo citadel, and across political boundaries, became servants of the state.

1 Ibn Iyās, Badā'ic al-Zuhūr, 3: 203.

(C) PATRICK WING, 2020 | DOI:10.1163/9789004431317_010

This is an open access chapter distributed under the terms of the CC BY-NC-ND 4.o liçense $t$ k Wing - 9789004431317 
The rise of the Banū Muzalliq was closely connected to the political and economic challenges facing the Sultanate of Cairo in the early fifteenth century. The accession of al-Z̄āhir Barqūq in 784/1382 has traditionally been understood as an important turning point in the history of the 'Mamluk' Sultanate. Barqūq's Circassian origins, his reliance on a well-cultivated circle of dependents and supporters, and his dispensing with the acknowledgement of a descendant of Qalāwūn as sultan have all been identified as important features of Barqūq's reign, marking a shift in the political culture of the Sultanate. ${ }^{2}$ The reign of his son and successor, al-Nāșir Faraj, has typically been viewed as a continuation of the Circassian revolution that Barqūq began, and evidence that Barqūq sought to establish a new dynastic tradition, based on his own lineage. At the same time, however, there are some good reasons for viewing Faraj's reign (801-815/1399-1412) as an important turning point in its own right, particularly when considering the place that Syria held in the Sultanate. Syria suffered traumatic economic and military setbacks in the first decade of the fifteenth century, brought on by a combination of crop failure, inflation, the invasion of Tìmūr in 803/1400-1401, and the subsequent civil war among military factions. In fact, there is good reason to think of Syria as basically falling out of the orbit of the Sultanate in Cairo, if not in the imagination of the political elite, then in practical terms. In general, the violent arrival of representatives of Chaghatayid Central Asia in the Nile-to-Oxus region in the latefourteenth and early fifteenth-centuries created great upheaval among the representatives of the post-Ilkhanid political order, and to the extent that Syria was connected economically and socially to Anatolia, Iraq and northwestern Iran, it too felt the impact of these disturbances. Although the Euphrates is often considered a significant political boundary, the fact was that for merchants, scholars, and even members of the military elite, Syria and the Ilkhanid realm were part of a continuum. Sultan Barqūq was able to maintain control of his realm to a reasonable degree during most of Tīmūr's early campaigns in Iran. However, after Faraj took the throne, military factions competing for influence over the young sultan became more and more powerful. ${ }^{3}$ Tīmūr's

2 The notion that Barqūq's reign represented a significant change in the history of the Sultanate is evident in the most common scheme of periodization in the field of Mamluk history, which has traditionally identified a "Turkish" or "Bahrī" period from 1250-1382, and a "Circassian" or "Burji”" period from 1382-1517. However, recent scholarship has begun to challenge the idea of an abrupt break with the past with Barqūq's accession, and emphasizes the ways in which Barqūq sought to merge his own dynastic ambitions with long-standing institutions and rituals. See Van Steenbergen, "Ritual, Politics, and the City in Mamluk Cairo", p. 265.

3 For a masterful study of the political conflicts among the Mamluk elite in the early $15^{\text {th }}$ century, see Onimus, Les Maîtres du Jeu, pp. 223-270. 
invasion of Syria and occupation of Damascus contributed to an already difficult economic situation, and left Syria open to political fragmentation once Tīmūr withdrew.

Accompanying these political challenges facing the Sultanate were two significant economic developments. One was the expansion of Venetian commercial influence in Syria in the early fifteenth century. ${ }^{4}$ A combination of factors in the last quarter of the fourteenth century had driven Venice out of Famagusta on Cyprus by the Genoese in 1373, Cilicia by the Sultanate's armies in 1375, and the northern Black Sea by Tìmūr in the 139os, thus making the Mediterranean ports, ${ }^{5}$ as well as Damascus and Aleppo, significant points of contact between Europe and the eastern silk and spice trade, via Venetian merchants. At the same time, Syro-Egyptian elites turned their attention to taxation of the transit trade, especially in spices, between the Indian Ocean and the Mediterranean in order to increase revenues that had declined from agrarian $i q t \bar{a} \mathrm{~s} .{ }^{6}$ Access to the spice trade required cooperation with other polities and merchant networks, including Venice. ${ }^{7}$ The Venetians thus became the main middlemen between the Cairo Sultanate and European markets in the fifteenth century. 8

The other significant economic development in the early fifteenth century was the rise of a new commercial elite operating within the Syro-Egyptian realm, seemingly replacing the so-called Kārimī merchants, who had dominated the eastern spice trade in the Indian Ocean and Red Sea from at least the Ayyubid period.$^{9}$ The height of the Kārimīs' power and influence coincided with the reign of Barqūq at the end of the fourteenth century. ${ }^{10}$ Yet, their wealth seems to have vanished along with the general collapse of the Egyptian economy at the beginning of the fifteenth century.11 As the influence of the Kārimīs declined, the activity of merchants in Syria seems to have increased. Trade expanded among both foreigners, mainly Venetians, as well as local merchant notables, often referred to collectively as khawājas, or khawājakiyya, as

4 Ashtor, Levant Trade, p. 324. Ashtor points out that the Venetians were especially active at Hama, Latakia, Tripoli, and Sarmin.

5 Ashtor, A Social and Economic History of the Near East, pp. 325-326.

$6 \quad$ Christ, Trading Conflicts, p. 33.

7 Christ, "Beyond the Network-Connectors of Networks", p. 28.

8 Arbel, "The Last Decades of Venice's Trade with the Mamluks", p. 37.

9 Apellániz Ruiz de Galarreta, Pouvoir et finance en Méditerranée pré-moderne, p. 268; Mortel, "The Mercantile Community of Mecca", p. 20.

10 Ashtor, "The Kārimī Merchants", p. 53.

11 Ashtor, "The Kārimī Merchants", p. 54. 
many of them were identified by this laqab..$^{12}$ However, there is some ambiguity about what this title actually meant in the context of the commercial economy. The title "khawäja" is of Persian origin, and has been used with a variety of meanings, depending on the period and place. In the case of Egypt and Syria, it came to be applied mainly to wealthy merchants working in official service to the sultan, who had come from outside his domains. ${ }^{13}$ It may also be a mistake to consider the khawajjakiyya as a distinct group operating only after about 1400. Sato Tsugitaka has identified the great slave trader Majd al-Dīn alSallāmī (d. 743/1342) who operated between Cairo and Tabriz as a khawāja merchant, ${ }^{14}$ and in fact has emphasized his business in slaves as setting him and his like apart from the Kārimīs, who dealt in the spice trade. ${ }^{15}$ Sato has also highlighted the career of the great khawajja slave merchant Fakhr al-Din 'Uthmān al-As'ardī (d. 783/1381), renowned for having imported Barqūq to Egypt from Circassia. As'ardī's qaysariyya, or market complex in Damascus, anchored his business in Syria as much as in Egypt. ${ }^{16}$

Richard Mortel has written on the large percentage of fifteenth century khawajja merchants in Mecca whose families hailed from other places. ${ }^{17}$ As Mortel has pointed out, many merchants with the title "khawäja" were born in Mecca, but had fathers with nisbas indicating they hailed from other places. ${ }^{18}$ During Barsbāy's reign, these merchants were recruited more directly into the service of the Sultanate as Barsbāy attempted to extend his personal control more fully over trade at Jedda and Mecca. One of the merchants who received the title murshidd of Jedda, an office that served as liaison between the sultan's officials and the merchant community in Jedda, was Shams al-Dīn Dā'ūd b 'Alī al-Kaylān̄ ${ }^{19}$ whose nisba indicated his family's origins in Gilan in northern

12 Ashtor, $A$ Social and Economic History of the Near East, p. 321.

13 Sato, "Slave Traders and Kārimī Merchants during the Mamluk Period", p. 143. The Encyclopaedia of Islam points out the variety of meanings that the title "khawäja", which is Persian in origin, has held throughout Islamic history, depending on the period and the place. In the Syro-Egyptian case, Qalqashandīs description of a "khawäja" as an important Persian or other foreign merchant was the primary way the title was applied, in contrast to the Ottoman case, where it became a designation of members of the 'ulama $\vec{a}$. See "Khwādja", Encyclopaedia of Islam, Volume 2 (Leiden: Brill), 4: 907.

14 Sato, "Slave Traders and Kārimī Merchants during the Mamluk Period", p. 144.

15 Sato, "Slave Traders and Kārimī Merchants during the Mamluk Period", pp. 152-154. Sato contrasts the slave traders with the Kārimīs by pointing out that the Kārimīs were engaged in more religious and cultural activities, while the slave traders came to be regarded as state officials, which the Kārimīs never were.

16 Sato, "Slave Traders and Kārimī Merchants during the Mamluk Period", p. 144.

17 Mortel, "The Mercantile Community of Mecca", p. 19.

18 Mortel, "The Mercantile Community of Mecca", p. 24.

19 Mortel, "The Mercantile Community of Mecca", p. 22. 
Iran. Mortel calculates that significant percentages of the great many merchants in Mecca who were immigrants were from Iran, Syria, and Egypt (with smaller numbers from Yemen, Iraq, and Anatolia). ${ }^{20}$

With the exception of Yemen, all of these places had been shaken by upheavals by the Timurids. The turmoil among Timur's descendants following his death in 1405 led to political fragmentation across Iran and Anatolia, as well as in Syria, where amirs took advantage of the chaos to compete for control of the Sultanate. The fact that the agricultural economy of Egypt was in decline, and was leading to the failure of the traditional system of revenue disbursement $\left(i q t \bar{a}^{c}\right)$ at the same time that these upheavals in the Timurid realm were taking place, meant that merchants with ties to far-flung markets would be valuable to the fiscal welfare of the Sultanate. Syria was brought back into the sultan's realm, beginning during al-Mu'ayyad Shaykh's reign (815/1412-824/1421), but the Syrian provinces were integrated with Egypt in a new way-the merchant elites operating in Syria, with connections to the Timurid realm and the Hijaz, became an important point of contact between the Sultanate in Cairo and the Levantine cities. This fact not only meant that the Syrian commercial elite would play a greater role in the projection of the sultan's authority, but also that its personnel would be shaped by a cosmopolitanism informed by social and cultural ties across a wide geographic area, from Cairo to Tabriz, and Aleppo to Mecca.

Francisco Javier Apellániz Ruiz de Galarreta has illustrated the ways that the khawajakiyya were incorporated into the administrative structures of the Sultanate. ${ }^{21}$ Although they remained private merchants, they acted in concert with the interests of the sultan, and received formal recognition for their services from Cairo. ${ }^{22}$ Apellániz Ruiz de Galarreta has argued that the khawāja merchants can be considered a privileged merchant guild under the protection of the Sultanate, comparable to the chartered trade companies of Spain and Portugal. ${ }^{23}$

An example of the wealth and prestige enjoyed by these new commercial elites can be found in the case of perhaps the greatest Syrian merchant family of the fifteenth century, the afore-mentioned Banū Muzalliq. The Muzalliq family had ties to the Hijaz, as well as with Syria, and this made them important in the economic and social integration of these regions by the Sultanate. The foundations of the family's wealth, and thus of their entrée into the Sultanate's

20 Mortel, "The Mercantile Community of Mecca", pp. 25, 35.

21 Apellániz Ruiz de Galarreta, Pouvoir et finance en Méditerranée pré-moderne, p. 103.

22 Apellániz Ruiz de Galarreta, Pouvoir et finance en Méditerranée pré-moderne, pp. 104-108.

23 Apellániz Ruiz de Galarreta, Pouvoir et finance en Méditerranée pré-moderne, p. 104. 
elite, was trade in the Indian Ocean. Shams al-Dīn Muhammad (d. 848/1444) made his fortune sailing to India, and was involved in commercial life in the Hijaz as well as in Syria. ${ }^{24}$ His relationship with the amir Shaykh al-Mahmmūdī, the future Sultan al-Malik al-Mu'ayyad, enabled him to leverage his commercial success in the Indian Ocean and Red Sea trade into a role valuable to the economy of the future sultan's household, and thence into the political hierarchy of the Sultanate. Shams al-Dīn Muhammad b. al-Muzalliq's family was one of several prominent Syrian merchant families who are designated as "khawajjas" in the sources, all of which traveled in common social circles in Damascus. ${ }^{25}$ The khawajja merchants were in a position to facilitate the transfer of wealth from trade to amirs competing for supremacy in Syria in the first decade of the 9 th $/ 15^{\text {th }}$ century. Damascus in particular was a city where conflict among amirs played out, largely due to the abundance of pious foundations (waqf) which could be seized to fund military operations. ${ }^{26}$ The two main factions in the civil war during the second reign of al-Nāșir Faraj (808/1405$815 / 1412$ ) were those of the amirs Shaykh al-Mahmmūdī and Nawrūz al-Ḥāfị̂i. ${ }^{27}$ In 811/1408, following his defeat of Nawrūz al-Hāfizīi and capture of Damascus, Shaykh al-Mahmūdī relied on Shams al-Dīn Muhammad to deliver 5,0oo dinars from the merchant community there. ${ }^{28}$ Shams al-Dīn's services paid off, as the Banu Muzalliq's relationship to the most successful amir in the conflict in Syria ensured their commercial privileges in Syria, and in the Sultanate writ large once Shaykh became sultan. Ibn al-Muzalliq's privileged status is confirmed in a document preserved by Qalqashandī, confirming his exemption from taxation in Egypt and Syria. ${ }^{29}$

For the next three decades, Shams al-Dīn Muhammad b. al-Muzalliq was known as kabir al-tujjär, head merchant at Damascus. His wealth not only allowed him to lay a foundation for his family's influence locally and throughout the Sultanate (more on this point below), but it also allowed him to reinvest in the commercial infrastructure of Syria. He paid for the improvement of roads, and built khans, or caravanserais, throughout Syria. According to the fifteenth century historian and biographer al-Sakhāwī, Shams al-Dīn Muhammad bequeathed a third of his wealth upon his death for the completion of a khan complex, while dividing the rest among the poor (fuqarä) of Mecca and Medina, Jerusalem, and Damascus. His influence extended well beyond his home

\footnotetext{
24 Apellániz Ruiz de Galarreta, Pouvoir et finance en Méditerranée pré-moderne, pp. 79-80.

25 Vallet, L'Arabie Marchande, p. 646.

26 Onimus, Les Maîtres du Jeu, p. 261.

27 Onimus, Les Maîtres du Jeu, p. 250.

28 Maqrīzì, Sulūk, 4: 72.

29 Labib, "Egyptian Commercial Policy in the Middle Ages", p. 75.
} 
city, and aligned well with the sultans' interest in maintaining control over Syria as well as its trade. ${ }^{30}$

Despite his wealth and status, Shams al-Dīn Muhammad was still vulnerable to changing political circumstances, illustrated by his imprisonment in 843/1439 following the accession of Sultan al-Zāhir Jaqmaq. Held in confinement in the Damascus citadel, Shams al-Dīn was only released after his son paid 5,000 dinars to the treasury, and 10,000 dinars to the dīwān al-khāṣs. ${ }^{31}$ In addition to providing a window into the extortionist practices of the central government, this incident also sheds light on the extent to which the new sultan looked to the Syrian merchant elite to fund his campaign to take the throne. The fact that the Muzalliq family delivered less than Jaqmaq demanded ${ }^{32}$ also suggests that they had some leverage for negotiation with the Sultanate. In any case, by the time of his death five years later at the age of more than eighty years, Ibn al-Muzalliq had become an essential part of the Sultanate's state in Syria. His importance to the ruling elite is exemplified by reports of the huge turnout at his funeral, attended by local elite ( $a^{\prime} y \bar{a} n$ ), including the governor of Damascus, the highest ranking official in Syria. ${ }^{33}$

Shams al-Dīn Muhammad's progeny benefited from their father's prominent position in the Sultanate. While one son, 'Umar, died before his father from the plague in 841/1437-1438, ${ }^{34}$ another son, Shihāb al-Dīn Aḥmad (d. 873/1468) became known as a successful merchant in his own right. Although he did not hold any government offices, ${ }^{35}$ Shihāb al-Dīn Ahmad did invest in the pious institutions of his city, establishing a kitchen (maṭbakh) near the Bāb al-Barīd, on the western side of the Umayyad Mosque in Damascus. However, the most significant member of the Muzalliq family in the generation after Shams al-Dīn Muhammad was his son Badr al-Dīn Ḥasan. He played a significant role in the extension of sultanic authority over trade at Jedda and Mecca during the reign of Sultan al-Ashraf Barsbāy (r. 825/1422-841/1438). In 841/1438, Barsbāy appointed Badr al-Dīn Hasan to the position of amir of Jedda, and dispatched him to that city along with the nāzir of Jedda, Sa'd al-Dīn Ibrāhīm b. al-Marra. ${ }^{36}$ The

\footnotetext{
30 Sakhāwī, al-Dạw' al-Lāmi', 8: 174; Sakhāwī, al-Tibr, 243.

31 Maqrīīì, Sulük, 4: 1157.

32 Maqrīzì writes that the sultan had demanded 30,0oo dinars for the treasury. See Maqrīīì, Sulūk, 4: 1157 .

33 Sakhāwī, al-Daw' al-Lāmi', 8: 174; Sakhāwī, al-Tibr, 243.

34 Sakhāwī, al-Tibr, 243.

35 Ibn Iyās, Badā'i 'al-Zuhūr, 3: 17.

36 Maqrīzī, Sulūk, 4: 1028, 1030; Ibn Fahd, Ithăf al-Wará, 4: 115-116. On the career of Ibn alMarra and his role in the extension of Mamluk authority to the Hijaz, see Wing, "Indian Ocean Trade and Sultanic Authority".
} 
Muzalliq family had thus by this time converted their prominence in Indian Ocean-Red Sea trade, as well as their alliance with the Sultanate, into a government position at the port of Mecca. This appointment was part of a larger process by which the Sultanate was attempting to bring the Hijaz more closely under the control of the sultan's own agents, appointed from Cairo, replacing the local dynasty of shariffs who had served as intermediaries between the Sultanate and the merchants there. ${ }^{37}$

Badr al-Dīn Hasan's other major appointment was from Sultan al-Ashraf Qāytbāy to the position of nāzir al-jaysh (army comptroller) of Damascus, in Dhū al-Qa'da 872/May-June 1468. ${ }^{38}$ This position signals the arrival of the Banū Muzalliq in the ranks of the Sultanate's political elite in an official capacity. Badr al-Din Hasan had begun his career at the side of his father as a merchant, was brought into the government hierarchy in Jedda by Barsbāy, and raised to a high office in the military administration under Qāytbāy.

Badr al-Dīn Hasan's son, Shams al-Dīn Muhammad, represented the third generation of the Banū Muzalliq, and a final phase of their incorporation into the Sultanate's ruling elite by the late $15^{\text {th }}$ century. We began this chapter by mentioning this Shams al-Dīn Muhammad, the namesake of his grandfather, and his appointment in 889/1484 to the office of Shāfici qā his father, Shams al-Dīn Muhammad acquired a position in the Sultanate's government apparatus. However, unlike his father, Shams al-Dīn Muhammad entered the ranks of the 'ulam $\bar{a}$, the religious scholars, who ostensibly served to ensure Islamic justice in the Sultanate. He continued in this role until he was murdered in his home in 902/1497. ${ }^{39}$

In the second chapter of this volume, Jan Dumolyn and Jo Van Steenbergen highlight Michael Chamberlain's contribution to our understanding of Marshall Hodgson's "military patronage state", particularly Chamberlain's emphasis on social relationships, rather than on legalistic bureaucratic offices, as a way to best understand the dynamics of politics within the military patronage state. In a description of the Seljuk Sultanate that might also be applied to the Sultanate of Cairo, Chamberlain described the state as "a collection of powerful households kept in check by the head of the most powerful among them". ${ }^{40}$ We might usefully ask where the Banū Muzalliq fit in to such a conception of the state? It may be useful to consider this elite merchant family as operating in two spheres: on one hand, as representatives of the sultan's own household,

37 See Meloy, Imperial Power and Maritime Trade, particularly chapter 4.

38 Ibn Iyās, Badā'i al-Zuhūr, 3: 14.

39 Ibn Iyās, Badā'i' al-Zuhūr, 3: 350.

40 Chamberlain, "Military Patronage States", p. 142. 
and agents of the extension of royal authority over other elite households and factions. On the other hand, the Banū Muzalliq, through their service to the sultan, also managed to establish an elite household of their own, that survived the fall of the Sultanate itself, and continued into the Ottoman period.

The Banū Muzalliq thus illustrate significant features of Syro-Egyptian state building in the 9th/15th century. They represent a merging of the political interests of the Sultanate with the commercial networks and wealth that the Syrian merchants could offer. They also represent the ways the family could leverage its relationship with the Sultanate to procure offices, property, and power within the political elite. Members of the family not only enjoyed privileged status as traders, but also acquired access to additional levers of power, all the while acting in roles of local patronage and investment in institutions of Islamic learning and devotion, in Damascus as well as in the Hijaz. The Banū Muzalliq were a cosmopolitan elite, whose rise within the Sultanate was not confined to a barracks or city quarter, but which put them in contact with a wider world of Middle Eastern and Mediterranean economic and political patterns.

Such a cosmopolitanism among the merchant elite should not surprise us, given what scholarship has shown us about networks of intellectuals and men of religion in the same period. Already by the middle of the fourteenth century there is evidence that the Sultanate was encouraging Hanafi legal scholars from outside Egypt and Syria, primarily from Anatolia and Iran, to train in the madrasas of Cairo. Leonor Fernandes has shown that the endowment documents (waqfiyya) from madrasas founded by prominent amirs in the second half of the fourteenth century stipulate "foreign" Hanafĩ students be appointed to positions in the madrasas. ${ }^{41}$ The purpose seems to have been to train a cadre of religious scholars that would serve as a counterweight to the influence of the local Shāfíi 'ulamä', who had traditionally enjoyed a privileged status and a good deal of power in the ongoing negotiation of moral authority between the military elite and the local population. ${ }^{42}$ As a result, the madrasas and khānqāhs of Syria and Egypt, and particularly Cairo, came to be filled by Turkish- and Persian-speaking individuals who forged ties with others

41 Fernandes, "Mamluk Politics and Education", pp. 91-93. Jo Van Steenbergen has shown how patronage of Hanafi jurists by the amir Yalbughā, who emerged as the main power behind the throne in the 1360 s, fit into a larger pattern of continuity in the cultural preferences and roles played by the Qalāwūnid sultans in the fourteenth century. See Van Steenbergen, "The Amir Yalbughā al-Khāṣṣakī, the Qalāwūnid Sultanate, and the Cultural Matrix of Mamlūk Society", pp. 439-441.

42 Fernandes, "Mamluk Politics and Education", p. 98; Levanoni, "Who were the 'Salt of the Earth", pp. 80-82. 
like them, as well as with the ruling elite who underwrote their education through the institutions they founded and endowed. The benefits did not flow one direction however. While the sultan and amirs provided the economic foundation for the 'ulama', the 'ulam $\bar{a}$ ' in turn lent spiritual legitimacy to the sultan's regime. ${ }^{43}$

The scholars who came to Cairo from Anatolia, Iran, and elsewhere formed their own informal networks. In addition to facilitating the exchange of scholarship, such networks could also facilitate contact with the sultan and other powerful individuals. An example can be seen in the life of Shaykh Badr al-Dīn Maḥmūd al-Simavī, best known for leading a rebellion against the Ottomans in 819/1416. Born and raised in Ottoman Thrace, Shaykh Badr al-Dīn, like so many scholars of his age, eventually made his way to Cairo to study logic and philosophy. Here he came into the circle of the well-known physician and master of occult sciences Shaykh Ḥusayn Akhlāțī (d. 799/1397). As İlker Evrim Binbaş has shown, Akhlāṭi had a profound influence on Shaykh Badr al-Dīn and helped to shape his ideas about mysticism and the occult, which informed his rebellion years later in the Ottoman lands. ${ }^{44}$ Sultan Barqūq himself had an interest in Sufism and the occult, ${ }^{45}$ and members of Akhlāțì's circle, many of whom hailed from Iran or Anatolia, ${ }^{46}$ enjoyed the favor of the court. Akhlāți himself was a close companion of Barqūq, while Shaykh Badr al-Dīn became tutor to Barqūq's son, the future Sultan al-Nāṣir Faraj. ${ }^{47}$

Thus, by the turn of the fifteenth century, the sultans in Cairo had begun to establish a pattern of ties and patronage among intellectuals who would challenge the orthodoxy of the traditional Egyptian 'ulam $\bar{a}$, and would both serve and benefit from their relationship with the ruling military elite. It seems that a similar development may have been underway with respect to integration of merchant networks, which crossed political boundaries in the same way the intellectual networks did, at a moment when the sultan and the political elite saw their fortunes tied increasingly to the commercial economy and when merchants operating across political boundaries and outside the control of the sultan's administrative apparatus, recognized the advantages of working for and under the protection of the sultan.

\footnotetext{
43 Lev, "Symbiotic Relations: Ulama and the Mamluk Sultans".

44 Binbaş, Intellectual Networks in Timurid Iran, pp. 122-140.

45 Binbaş, Intellectual Networks in Timurid Iran, p. 117.

46 Binbaş, Intellectual Networks in Timurid Iran, pp. 132-135, idem, "The Anatomy of a Regicide Attempt", pp. 411-412.

47 Binbaş, Intellectual Networks in Timurid Iran, p. 126; Muslu, The Ottomans and the Mamluks, p. 74 .
} 


\section{Conclusion}

The Banū Muzalliq were products of the political and economic circumstances of the 9 th $/ 15^{\text {th }}$ century, and their rise and integration into the Syro-Egyptian political elite suggest some realities of state formation in the Sultanate. First, the conflicts among amirs in the first decade of the 9 th $/ 15$ th century meant that Syria would play a role apart from Egypt, but also central to the factional struggles of the period. In these struggles, and particularly during the last phase of civil war between the factions of Shaykh al-Mahmūdī and Nawrūz al-Ḥāfizị, wealth from Syria, taken in the form of taxes from local populations, played an important role. Shams al-Dīn Muhammad b. al-Muzalliq was able to serve the immediate local political interests of the amirs (Shaykh in particular), through his success in the transregional commercial ventures that connected the Indian Ocean, Red Sea, and Mediterranean in this period. Ibn al-Muzalliq thus offered a valuable service to the amir, and later Sultan al-Mu'ayyad Shaykh, as well as his successor, al-Ashraf Barsbāy. Taking over from his father, the kabir al-tujjār of Damascus, Shams al-Dīn Muḥammad's son, Badr al-Dīn Ḥasan, moved into administrative roles that signaled both his family's rise to prominence, as well as the Sultanate's dependence on trade in the Hijaz and Levant for its economic prosperity. By the third generation, Shams al-Dīn Muhammad b. Badr al-Dīn Ḥasan had solidified the family's influence over both trade and the levers of legal authority, including over awqā $f$, as chief $q \bar{a} d \bar{\imath}$ of Damascus. The Banū Muzalliq thus illustrate a path to the political elite that did not begin in the citadel or a madrasa. That is, this family of merchants were outsiders, whose connections and influence at the peripheries of the Cairo Sultanate made them valuable partners in the state's extension of its authority via loyal agents of the sultan.

\section{Bibliography}

\section{Primary Sources}

Ibn Fahd, 'Umar b. Muhammad, Ithăf al-Wará bi-Akhbār Umm al-Qurá, Fahīm Muhammad Shaltūt, ed., (Mecca, 1983-1990).

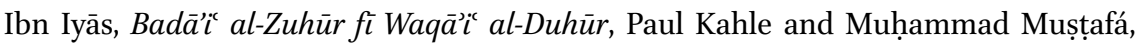
eds., volume 3 (Istanbul, 1936).

Maqrīzī, Aḥmad ibn 'Alī, Kitāb al-Sulūk li-Ma'rifat Duwal al-Mulūk, Muḥammad Mușțafá Ziyāda ed., volume 4 (Cairo, 1934).

Sakhāwī, Muḥammad b. 'Abd al-Raḥmān, al-Daw'al-Lāmi' li-Ahl al-Qarn al-Tāsi', 'Abd al-Lațîf Ḥasan 'Abd al-Raḥmān, ed., 12 vols. (Beirut, 2003). 
Sakhāwī, Muḥammad b. 'Abd al-Raḥmān, al-Tibr al-Masbūk fì Dhayl al-Sulūk, Saīì 'Abd al-Fattāḥ 'Āshūr, volume 1 (Cairo, 2002).

\section{Secondary Sources}

Apellániz Ruiz de Galarreta, Francisco Javier, Pouvoir et finance en Méditerranée prémoderne: le deuxième État mamelouk et le commerce des épices (1382-1517) (Barcelona, 2009).

Arbel, Benjamin, "The Last Decades of Venice's Trade with the Mamluks: Importations into Egypt and Syria", Mamlūk Studies Review 8/2 (2004): 37-86.

Ashtor, Eliyahu, "The Kārimī Merchants", Journal of the Royal Asiatic Society 1/2 (1956): $45^{-5}$.

Ashtor, Eliyahu, A Social and Economic History of the Near East in the Middle Ages (London, 1976).

Ashtor, Eliyahu, Levant Trade in the Later Middle Ages (Princeton, 1983).

Binbaş, İlker Evrim, "The Anatomy of a Regicide Attempt: Shāhrukh, the Hurūfīs, and the Timurid Intellectuals in 830/1426-27", Journal of the Royal Asiatic Society 23/3 (2013): 391-428.

Binbaş, İlker Evrim, Intellectual Networks in Timurid Iran: Sharaf al-Dīn 'Al̄̄ Yazdī and the Islamicate Republic of Letters (Cambridge, 2016).

Chamberlain, Michael, "Military Patronage States and the Political Economy of the Frontier, 1000-1250", in Y.M. Choueiri, ed., A Companion to the History of the Middle East (Chichester, 2008), 135-153.

Christ, Georg, "Beyond the Network-Connectors of Networks: Venetian Agents in Cairo and Venetian News Management", in Everything is on the Move: The Mamluk Empire as a Node in (Trans-) Regional Networks, ed. Stephan Conermann (Bonn, 2014), 27-59.

Christ, Georg, Trading Conflicts: Venetian Merchants and Mamluk Officials in Late Medieval Alexandria (Leiden, Boston, 2012).

Darrag, Ahmad, L'Égypte sous le règne de Barsbāy: 825-841/1422-1438 (Damascus, 1961).

Fernandes, Leonor, "Mamluk Politics and Education: The Evidence from Two Fourteenth Century Waqfiyya", Annales Islamologiques 23 (1987): 87-98.

Labib, Subhi, "Egyptian Commercial Policy in the Middle Ages", in M.A. Cook, ed., Studies in the Economic History of the Middle East (London, 1970), pp. 63-77.

Lev, Yaacov, "Symbiotic Relations: Ulama and the Mamluk Sultans", Mamlūk Studies Review 13/1 (2009): 1-26.

Levanoni, Amalia, "Who were the 'Salt of the Earth' in Fifteenth-Century Egypt?", Mamlūk Studies Review 14 (2010): 63-83.

Manz, Beatrice Forbes, “Temür and the Problem of a Conqueror's Legacy", Journal of the Royal Asiatic Society 8 (1998): 21-41. 
Martel-Thoumian, Bernadette, Les civils et l'administration dans l'état militaire mamlūk (IX/XV siècle) (Damascus, 1992).

Martel-Thoumian, Bernadette, "The Sale of Office and its Economic Consequences during the Rule of the Last Circassians (872-922/1468-1516)", Mamlük Studies Review $9 / 2$ (2005): 49-83.

Meloy, John L., Imperial Power and Maritime Trade: Mecca and Cairo in the Later Middle Ages (Chicago, 2010).

Mortel, Richard T., "The Mercantile Community of Mecca during the Late Mamlūk Period", Journal of the Royal Asiatic Society 4 (1994): 15-35.

Muslu, Cihan Yüksel, The Ottomans and the Mamluks: Imperial Diplomacy and Warfare in the Islamic World (London and New York, 2014).

Onimus, Clément, Les Maîtres du Jeu: Pouvoir et Violence Politique à l'Aube du Sultanat Mamlouk Circassien (784-815/1382-1412) (Paris, 2019).

Sato, Tsugitaka, "Slave Traders and Kārimī Merchants during the Mamluk Period: A Comparative Study", Mamlūk Studies Review 10/1 (2006): 141-156.

Vallet, Éric, L'Arabie Marchande: État et commerce sous les sultans Rasūlides du Yémen (626-858/1229-1454) (Paris, 2010).

Van Steenbergen, Jo, "The Amir Yalbughā al-Khāșșakī, the Qalāwūnid Sultanate, and the Cultural Matrix of Mamlūk Society: A Reassessment of Mamlūk Politics in the 136os", Journal of the American Oriental Society 131/3 (2011): 423-443.

Van Steenbergen, Jo, "Revisiting the Mamlūk Empire. Political Action, Relationships of Power, Entangled Networks, and the Sultanate of Cairo in late medieval Syro-Egypt", in R. Amitai \& St. Conermann, eds., The Mamluk Sultanate from the Perspective of Regional and World History. (Mamluk Studies 16) (Bonn \& Göttingen, 2019), pp. $77^{-108}$.

Van Steenbergen, Jo, "Ritual, Politics, and the City in Mamluk Cairo: The Bayna l-Qașrayn as a Dynamic 'Lieu de Mémoire', 1250-1382", in Alexander Beihammer, Stavroula Constantinou, and Maria Parani, eds., Court Ceremonies and Rituals of Power in Byzantium and the Medieval Mediterranean: Comparative Perspectives (Leiden, 2013), pp. 227-276.

Wing, Patrick, "Indian Ocean Trade and Sultanic Authority: The nāzir of Jedda and the Mamluk Political Economy", Journal of the Economic and Social History of the Orient 57/1 (2014): 55-75. 